$1-1-1974$

\title{
Partial in-house drying and mechanical removal of manure from caged laying hens
}

\author{
A. D. Longhouse
}

Follow this and additional works at: https://researchrepository.wvu.edu/ wv_agricultural_and_forestry_experiment_station_bulletins

\section{Digital Commons Citation}

Longhouse, A. D., "Partial in-house drying and mechanical removal of manure from caged laying hens" (1974). West Virginia Agricultural and Forestry Experiment Station Bulletins. 632.

https://researchrepository.wvu.edu/wv_agricultural_and_forestry_experiment_station_bulletins/542 @ WVU. It has been accepted for inclusion in West Virginia Agricultural and Forestry Experiment Station Bulletins by an authorized administrator of The Research Repository @ WVU. For more information, please contact ian.harmon@mail.wvu.edu. 
Irtial In-House Drying And Mechanical Removal of Manure From Caged Laying Hens

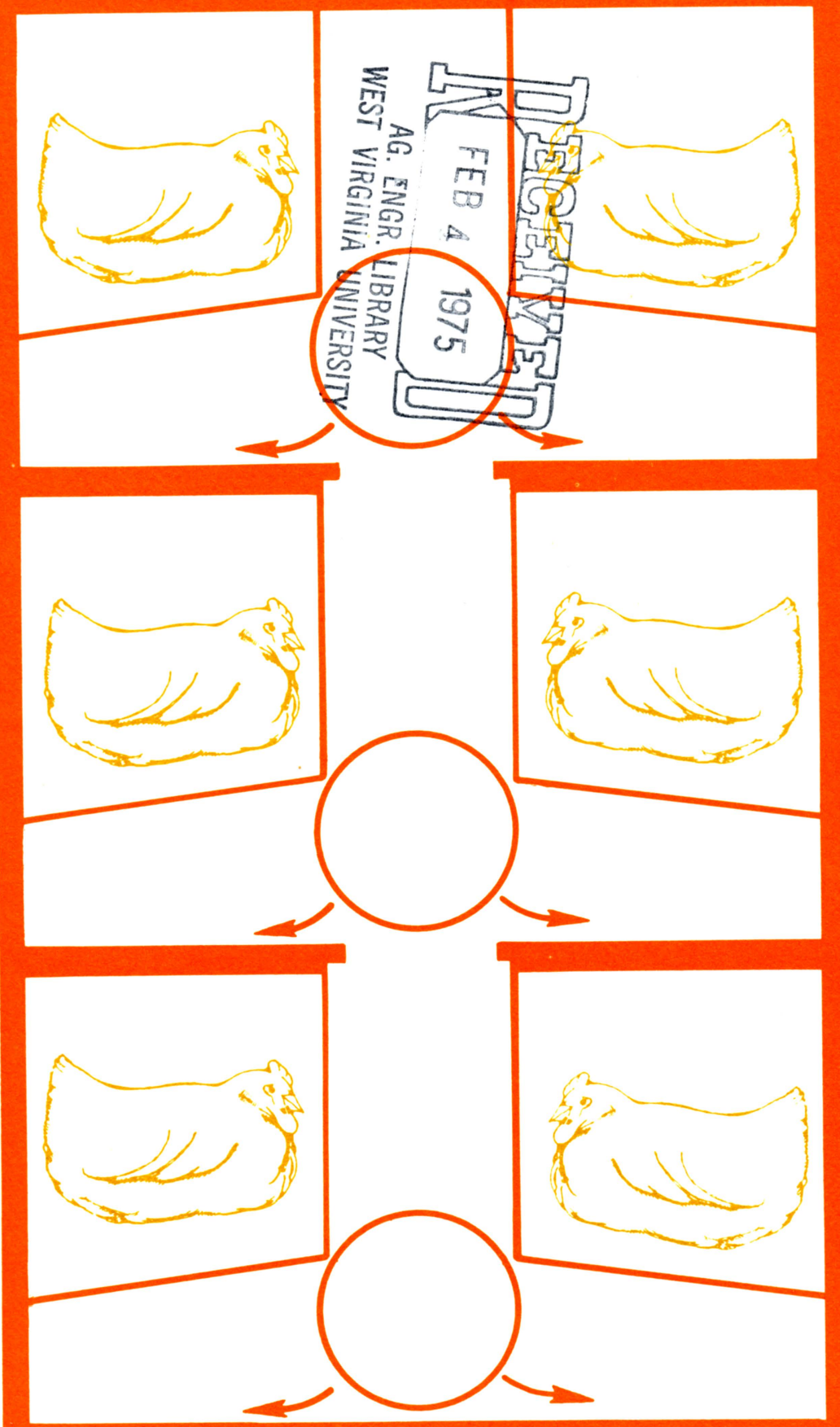

Woct Virginia Inivercity Arricultural Fxperiment Station 


\title{
CONCLUSIONS
}

A substantial portion of the moisture in poultry manure may be evaporated by using in-house air as the manure accumulates beneath the cages. This reduces the weight of the manure removed, improves its handling characteristics, and helps control odors and flies.

The use of conveyor belts under cages provides an extremely effective means of removing the manure and contributes to the control of odors and flies. The belts eliminate the need for labor to periodically clean the pits used in many cage systems.

The data presented in Table 3 is for one strain (Babcock 300) of laying hens for two months (June and July). Tests will be run during the cold weather months to determine the effectiveness of room air to remove moisture from the manure.

As the auxiliary air rate $(\mathrm{cfm} / \mathrm{bird})$ increased, the rate of the exchange air decreased from the beginning rate (four $\mathrm{cfm} / \mathrm{bird}$ ) when no auxiliary air was used. This was not intended to occur, but it may be a desirable means of controlling the rate of exchange during cold weather if only the air supply (fan) is used to recirculate and exchange air.

Placing cages vertically makes it possible to house more birds on the same floor area than with the stair-step system.

\section{THE AUTHOR}

A. D. Longhouse is Agricultural Engineer.

\author{
West Virginia University \\ Agricultural Experiment Station \\ College of Agriculture and Forestry \\ Homer C. Evans, Acting Director \\ Morgantown
}




\section{Partial In-House Drying And Mechanical Removal of Manure From Caged Laying Hens}

\section{A. D. Longhouse}

The trend to increase the density of laying hens in totally confined, windowless houses has made egg production more efficient, often at the expense of increased air pollution. Large commercial flocks on small land areas make it difficult to dispose of the solid wastes, especially adjacent to urban areas. Thus, the management of these operations, in order to stay in business, must find ways and means of substantially reducing odors and flies.

\section{OBJECTIVES}

The objectives for this research were (1) to investigate the possibilities of using conveyor belts under caged laying hens to remove the manure and (2) to partially dry the manure as it accumulated on the belt using recirculated in-house air.

The research was conducted in a chamber $10^{\prime} \mathrm{W} \times 12^{\prime} \mathrm{L} \times 8^{\prime} \mathrm{H}$ in the Agricultural Engineering Building at West Virginia University.

\section{CAGE ARRANGEMENT}

Model No. 1 (Conveyor belts only)

Placing two rows of cages back to back in a vertical arrangement three tiers high makes the unit 32" wide (inside the support posts) that will house 18 hens per foot of length (Figures 1 and 2). The unit is 8' long, so it houses 144 hens at maximum capacity.

Conveyor belts under each tier of cages provide an efficient means of removing the manure. The belts are the same width as the double row of cages. A fractional horsepower motor and speed reducer drives the three belts at a speed of 15' per minute. The belts extend beyond the ends of the cages to make sure all manure is collected at each level (Figure 2). Mounting the feed and water troughs on the outside of the vertical posts prevents most of the feed and all of the water from spilling onto the belts. Some feed is "billed" onto the belts by the birds. If the water troughs overflow, it is into the feed troughs below or onto the floor. 


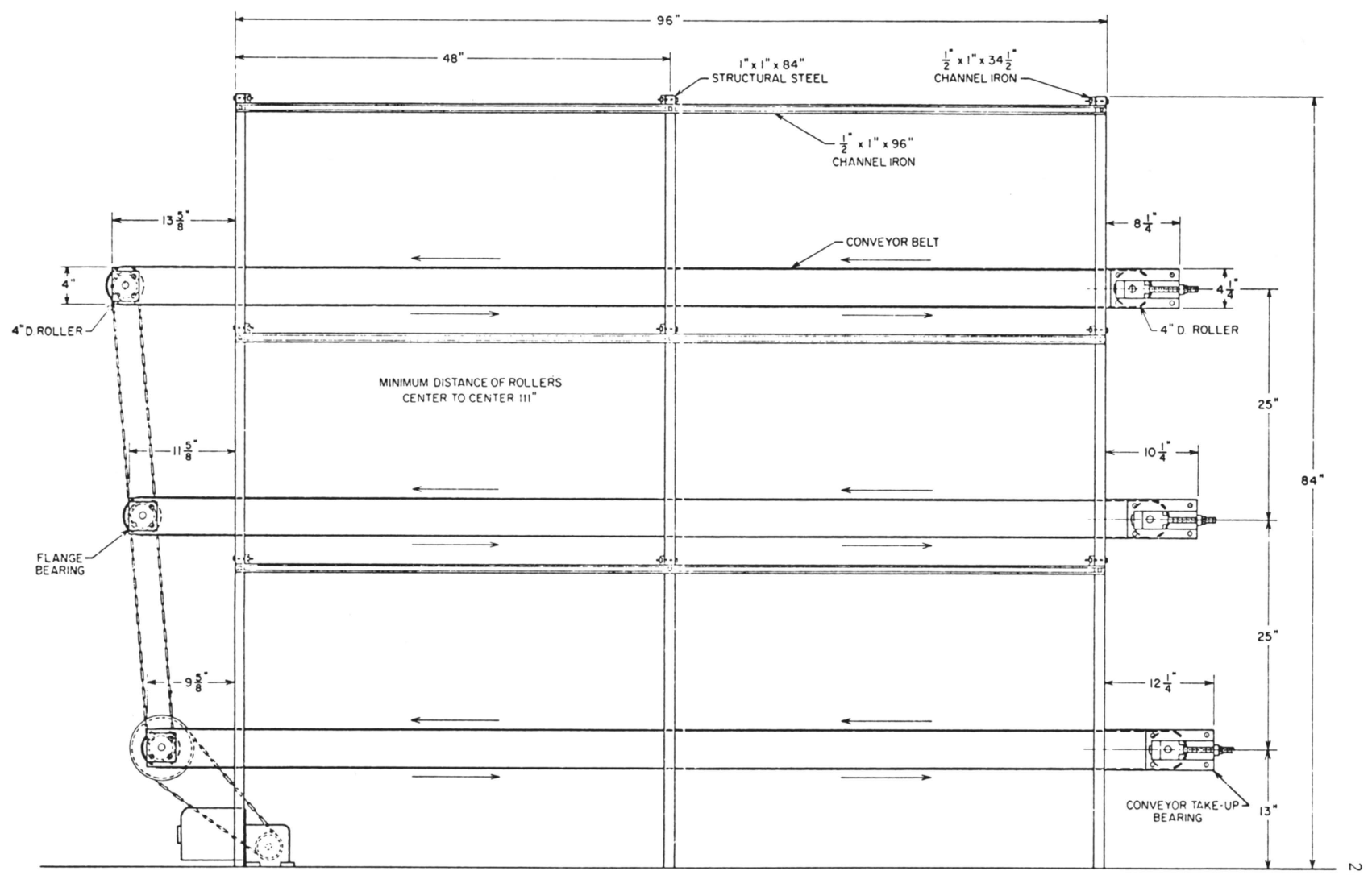

Figure 1. Side Elevation of Framing with Belt Conveying System 


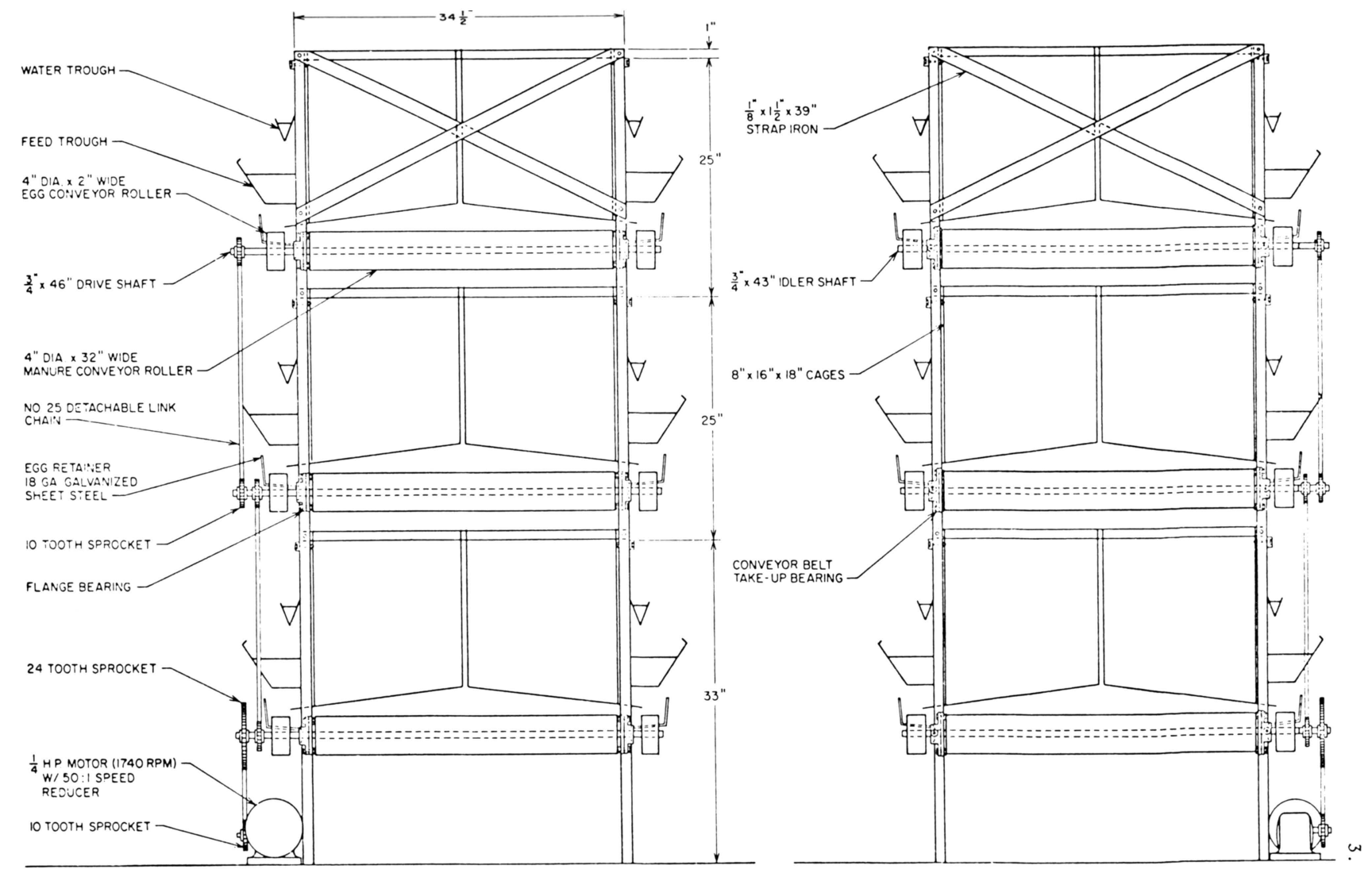

Figure 2. Drive End (left view) and Idler and Belt Adjustment End (right view) of Belt Conveying System 
Model No. 2 (Conveyor belts and air re-circulation system)

This unit is essentially the same as Model No. 1 described above except the cages are 18" deep. They are spaced 6" apart to accommodate a duct system to provide auxiliary air to dry the manure as it accumulates on the belts (Figures 3 and 4).

Scraper blades remove the manure that clings to the belts as they leave the drive rollers. The pressure exerted on the belts by the scrapers is controlled by counter weights and an adjustable lever (Figures 3 and 4).

In-house (chamber) air is used in the auxiliary air duct system (Figures 5 and 6). The inlet of a 1-1/2-hp centrifugal blower is connected to the exhaust air system, thus recirculating a portion of the in-house air. Free delivery from this blower provides more air than is likely to be needed for 144 laying hens. For research purposes, the rate of air flow is varied with orifice plates of different diameters placed in the inlet duct. Air from the blower, that is mounted outside of the chamber, enters a duct to return the air into the chamber through an opening at each tier of cages (Figure 6). The air leaves the distribution ducts through holes $0.5^{\prime \prime}$ diameter spaced 3" o.c. (Figures 4,5 , and 6).

The ventilation system for the chamber is shown in Figure 5 . Air enters the chamber through six 6" $\times 12^{\prime \prime}$ openings near the floor (three on each side) and it is exhausted through similar outlets near the translucent plastic ceiling (Figure 7). The air leaving the chamber through the six openings enters ducts that are joined to a common duct that extends diagonally over the top of the chamber of the exhaust fan (Figure 5).

\section{BELT MATERIAL}

At present, 5 mil mylar plastic is being used for the manure conveyor belts. Ten mil mylar is on hand in case the 5 mil proves to be too light. Obviously, heavier belting will be required for commercial operations.

\section{MANAGEMENT OF THE CHAMBER}

Light is provided for 14 hours, from 8 a.m. until 10 p.m. daily. The intensity of the flourescent lights is controlled by a dimming device. Water is provided for 15 minutes each hour during the "daylight" hours. Temperature and humidity are recorded for the entering and exhaust air. Each test is conducted for a minimum of five consecutive days, Monday through Friday, allowing the weekend for changes and/or adjustments for the next test or to repeat the same test, if necessary. 


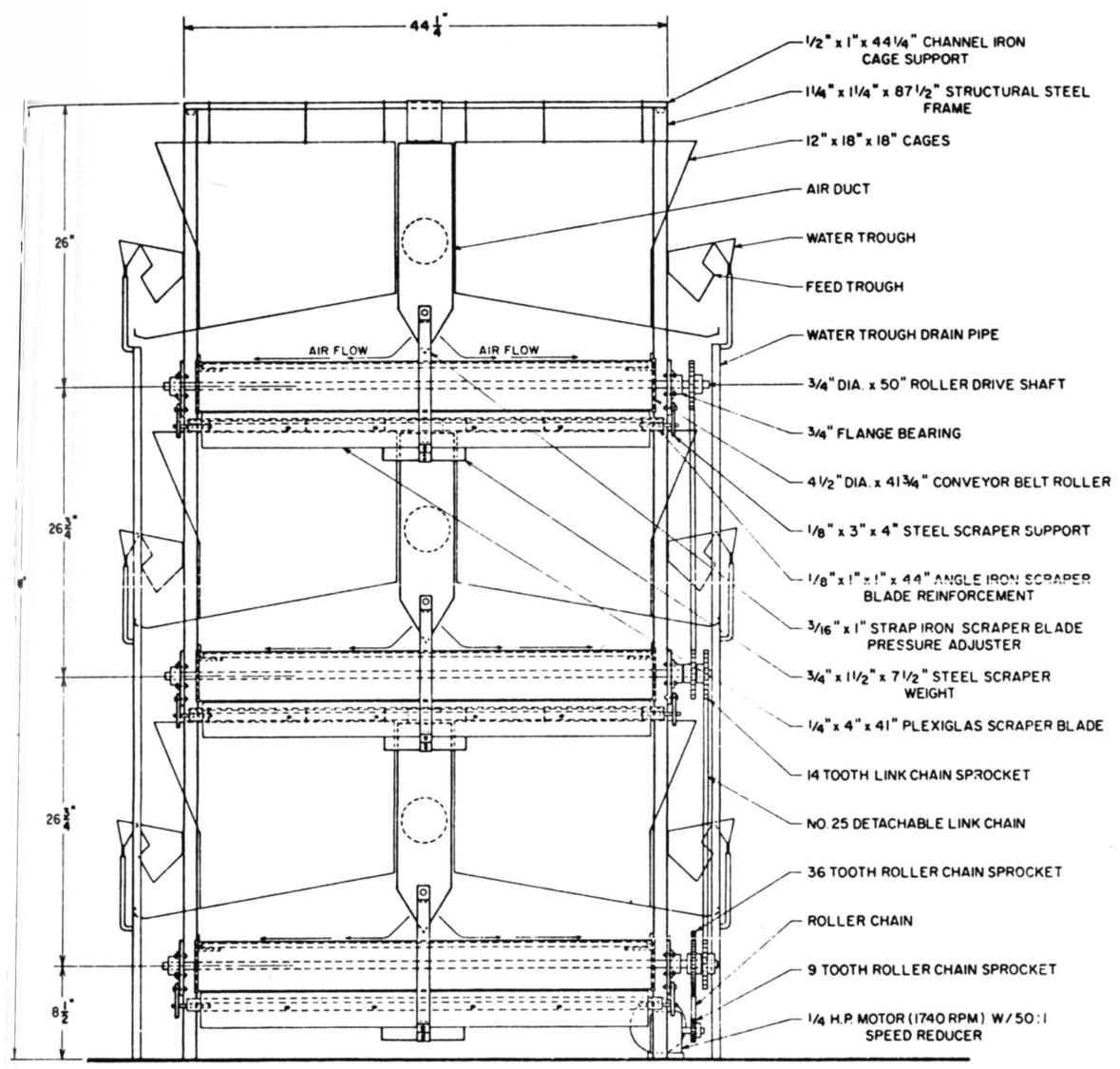

Figure 3. End Elevation of Auxiliary Air and Belt Conveying System 


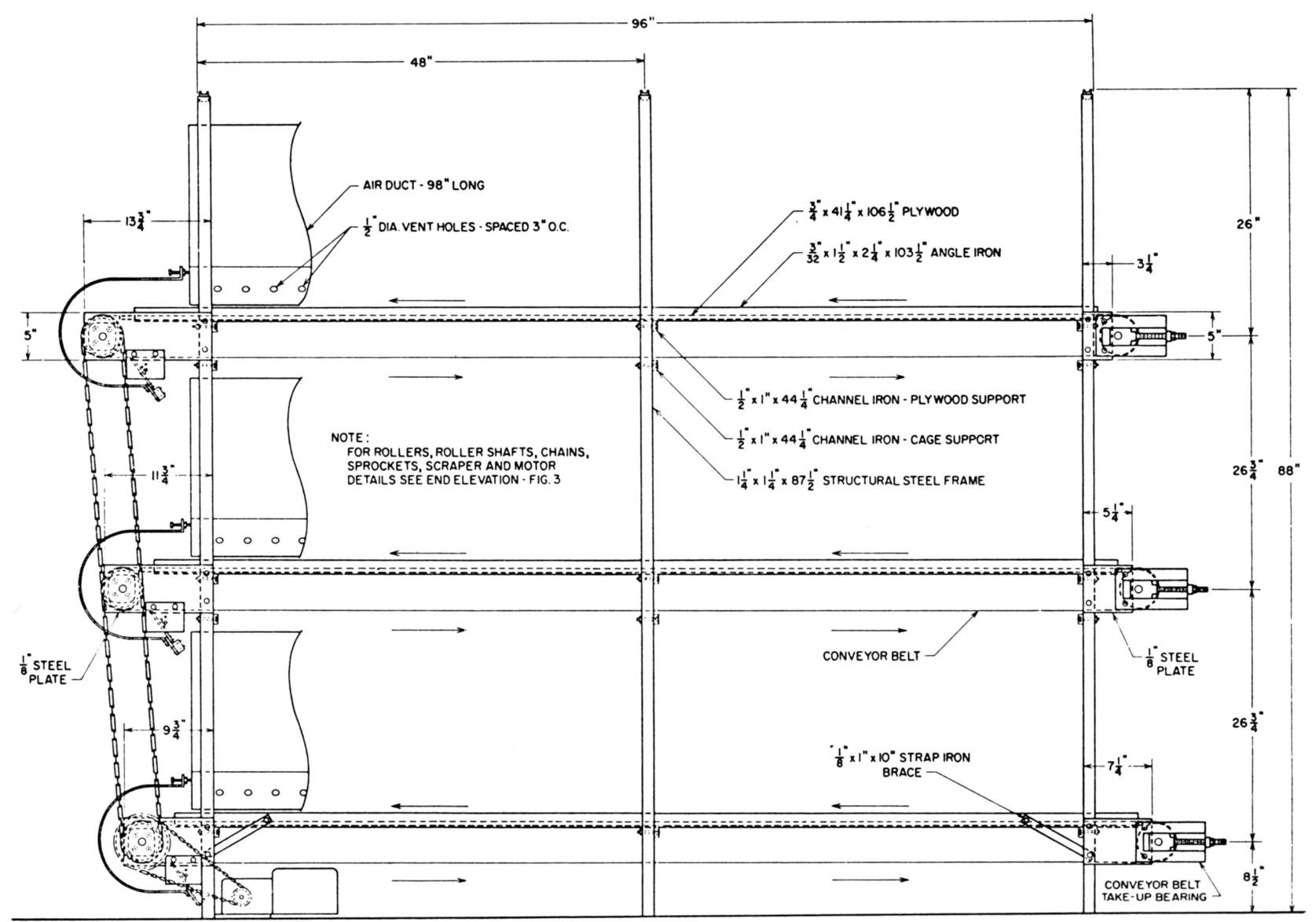

Figure 4. Side Elevation of Auxiliary Air and Belt Conveying System 


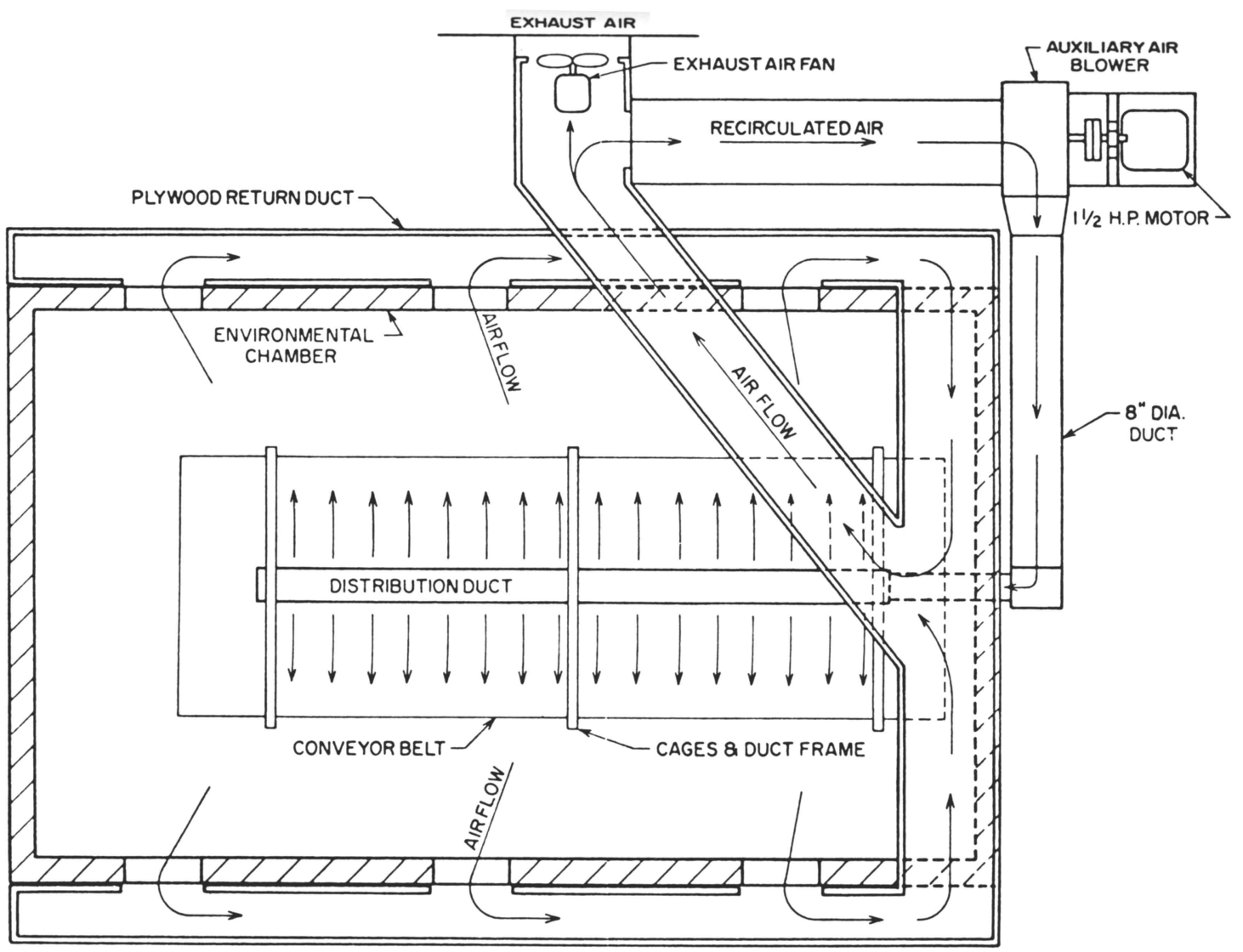

Figure 5. Plan View of Ventilation and Recirculated Air Systems 


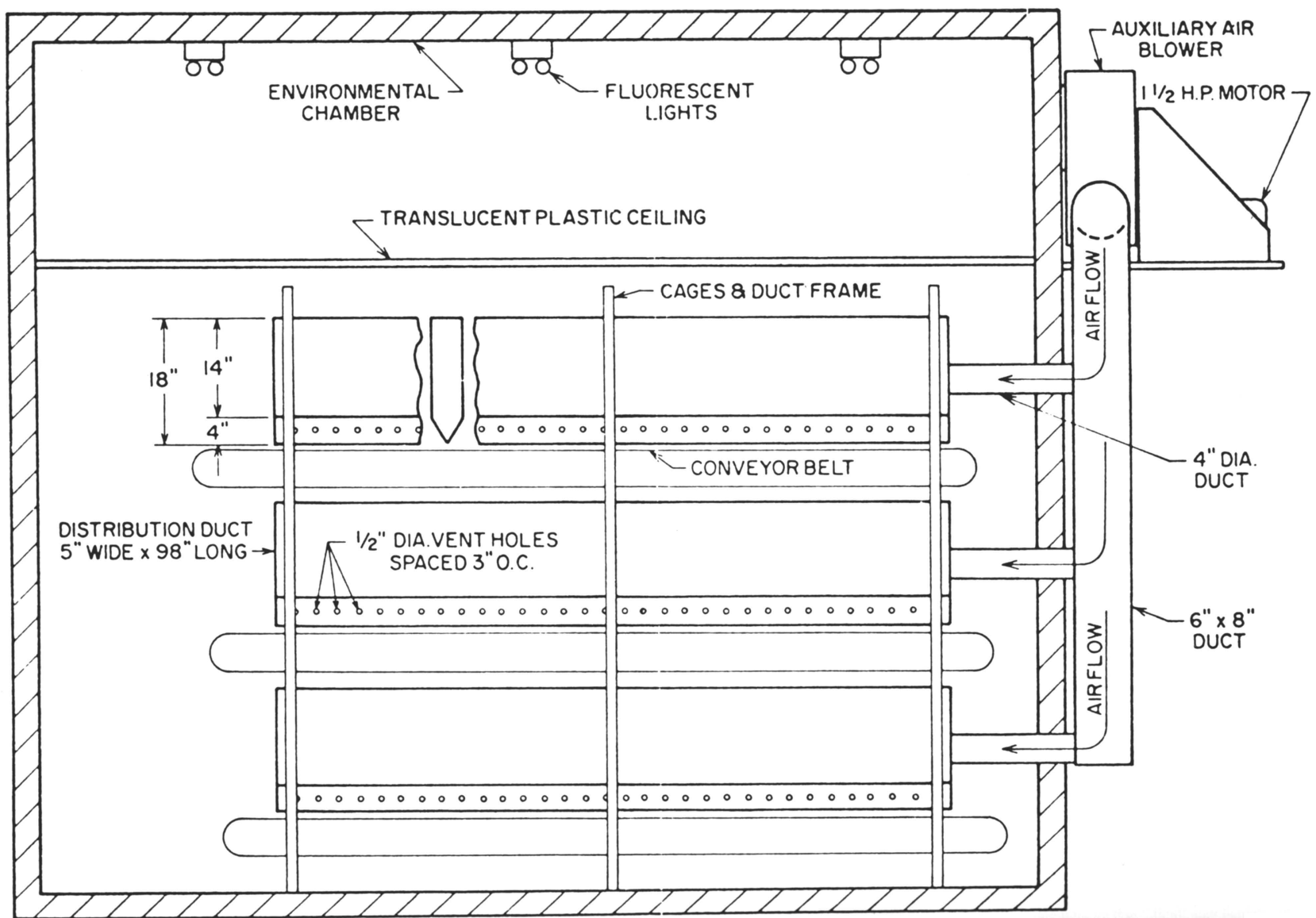

Figure 6. Side Elevation of Chamber, Cage Framing, Conveyors, and Recirculated Air Ducts 


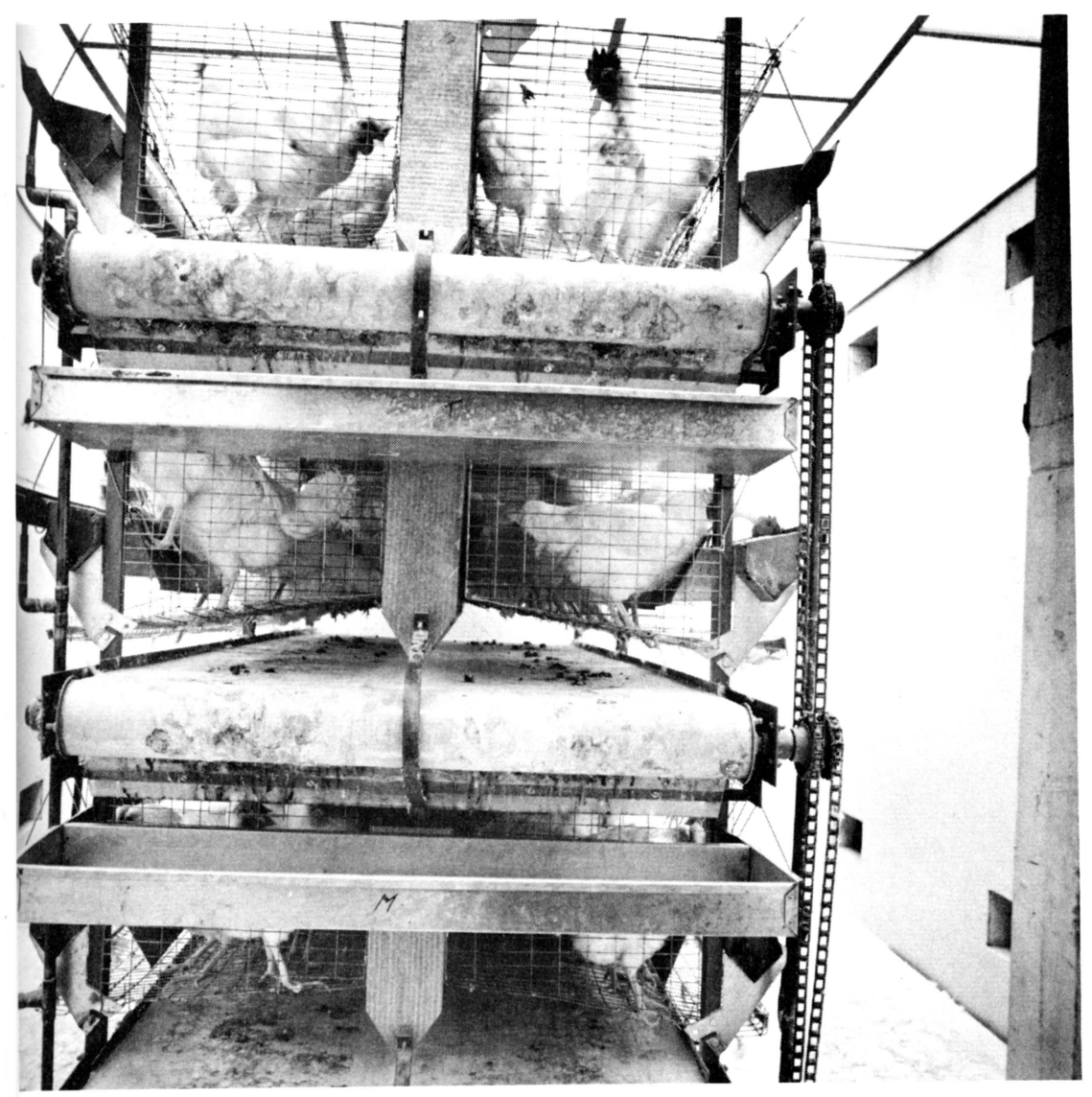

Figure 7. Vertical Cage Facility in the Center of the Chamber Showing Position of Air Inlet and Exhaust Openings

\section{RATE OF MANURE ACCUMULATION}

To design a complete mechanical system for removing and processing poultry manure, it is essential to know the rate the manure collects on the conveyor belts during a 24-hour period. Thus, it is necessary to know the uniformity of the rate and what portion of the droppings are collected during the "daylight" hours and during the hours of total darkness. The results of one 24-hour test are shown in Figure 8. Although 112 White Leghorn laying hens were involved, the data are presented for 100 hens.

A time clock turned on the lights at 8 a.m. and off at 10 p.m. daily. All manure was removed from the conveyor belts at 8 a.m. Beginning at 9 a.m. all 


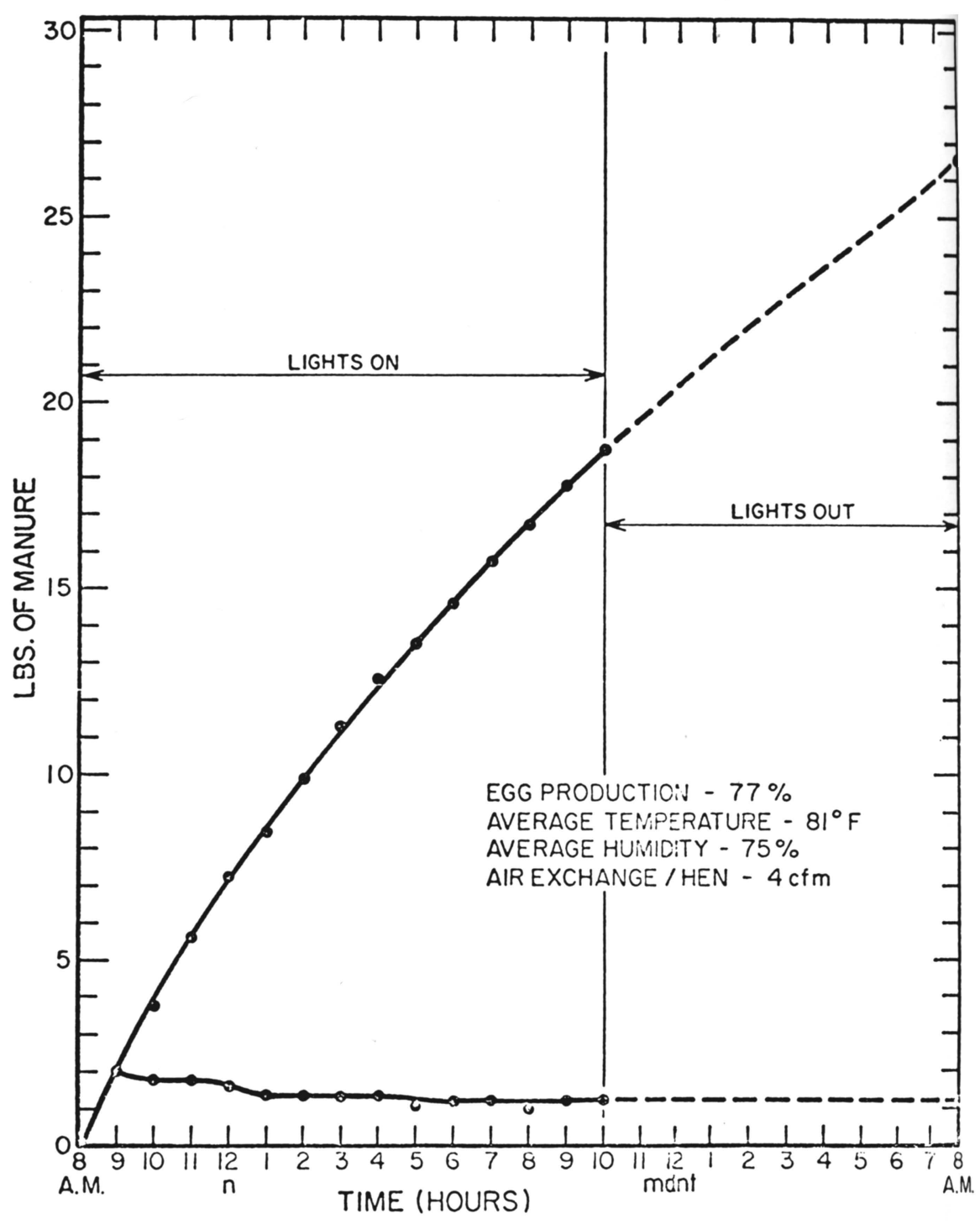

Figure 8. Accumulation of Manure Under Vertically Tiered Cages for One 24-Hour Period for 100 White Leghorn Laying Hens 
manure was removed and weighed every hour on the hour until 10 p.m. when the lights were turned off. The solid line of the upper curve in Figure 8 represents the rate of accumulation of the manure on the conveyor belts while the solid portion of the lower curve represents the number of pounds of manure collected each hour for 14 hours ( 8 a.m. to 10 p.m.). The broken portion of each curve is extended to 8 a.m. the next day when the manure was removed and weighed for the 10 hours of darkness. The 100 hens produced 26.56 pounds of manure during the 24 -hour period. Of this total, 18.86 pounds were collected during the 14-hour "daylight" period and 7.70 pounds during the 10 hours of darkness. During this one 24-hour test, the moisture content of the manure collected during the first hour of light (8-9 a.m.) was 84 per cent (wet basis), while the moisture content of a sample taken at 10 p.m. (9-10 p.m.) was 77 per cent (wet basis). Previous research, where moisture content determinations were based on samples taken during the first hour the lights were on ranged between 80 and 86 per cent (wet basis). This appears to be the wrong time to obtain the average moisture content of fresh manure for a 24-hour period. An inspection of the accumulation curve (Figure 8) would indicate a gradual decline in the accumulation of manure. Also, the lower curve (Figure 8) shows that $\mathbf{2 . 0 0}$ pounds of manure were collected during the first hour. Then, there was a slight, but steady, decline to 1.25 pounds at 10 p.m. when hourly weighing was discontinued.

A second test was made two weeks later with the same laying hens. This time the manure was removed at two-hour intervals for $\mathbf{2 4}$ hours (Figure 9). Overall, there was a steady decline in the weight of the manure collected every two hours until early the next morning (2-4 a.m.) when it began to increase. Likewise, the weight of the dry material and moisture content (85.22 per cent) occurred during the first two hours of light (8-10 a.m.). The minimum weight (1.55 pounds) was collected between 12 and 2 a.m. The least moisture content (76.64 per cent) occurred in the manure collected between 10 and 12 p.m. (Table 1). These data show that it would be erroneous to assume the 85.21 per cent moisture in the manure collected from 8-10 a.m. represented the average moisture for $\mathbf{2 4}$ hours (Table 1 ).

Although there was some variation in the quantity of manure produced each two-hour period, the per cent moisture showed a steady decline from 85.21 (8-10 a.m.) to 81.64 (2-4 a.m.) then rose slightly to 81.77 (6-8 a.m.) (Table 2). The total accumulation of fresh manure for 100 laying hens in 24 hours was 32.32 pounds. The total weight of the dry material was 5.889 pounds and moisture $\mathbf{2 6 . 4 3 1}$ pounds which gave an average moisture content of $\mathbf{8 1 . 7 7}$ per cent (Table 2). 


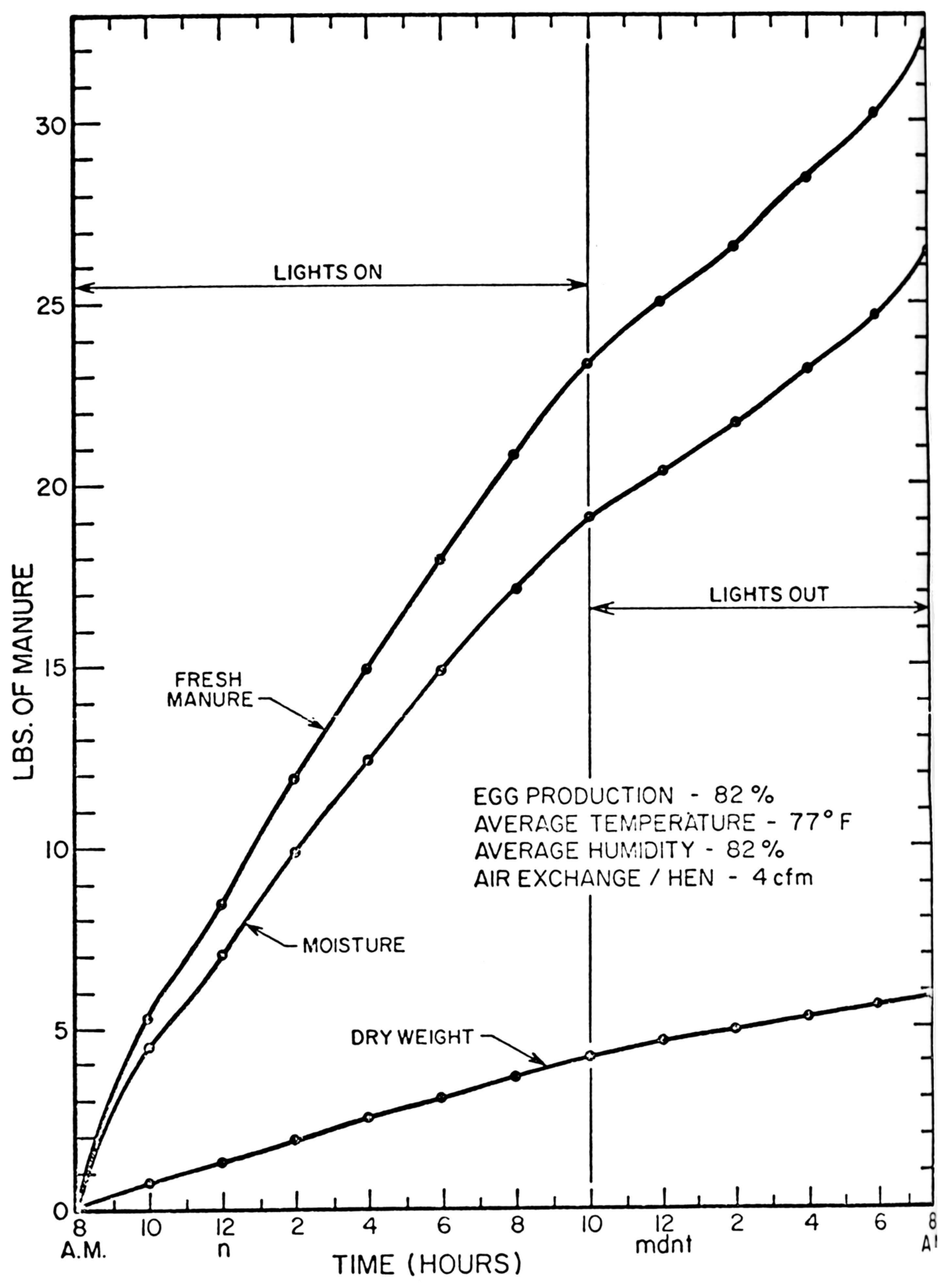

Figure 9. Rate of Accumulation, Moisture and Dry Weight Content of Manure from 100 Laying Hens for 24 Hours 


\section{TABLE 1}

Weight of Fresh Manure, Moisture, and

Dry Material Collected From 100 Laying

Hens Every 2 Hours for 24 Hours

\begin{tabular}{|c|c|c|c|c|}
\hline Time $^{1}$ & $\begin{array}{c}\text { Fresh } \\
\text { Weight }^{2} \\
\text { (Ibs.) }\end{array}$ & $\begin{array}{c}\text { Dry } \\
\text { Weight } \\
\text { (lbs.) }\end{array}$ & $\begin{array}{c}\text { Moisture } \\
\text { Weight } \\
\text { (Ibs.) }\end{array}$ & $\begin{array}{c}\text { Moisture } \\
\text { Content } \\
\text { (per cent) }\end{array}$ \\
\hline 8-10 AM & 5.284 & 0.781 & 4.503 & 85.22 \\
\hline $10-12 \mathrm{AM}$ & 3.194 & 0.595 & 2.599 & 81.36 \\
\hline 12-2 PM & 3.351 & 0.567 & 2.784 & 83.06 \\
\hline 2-4 PM & 3.109 & 0.563 & 2.546 & 81.89 \\
\hline 4-6 PM & 2.955 & 0.533 & 2.422 & 81.96 \\
\hline 6-8 PM & 2.856 & 0.583 & 2.273 & 79.58 \\
\hline 8-10 PM & 2.495 & 0.519 & 1.976 & 79.21 \\
\hline 10-12 PM & 1.685 & 0.394 & 1.291 & 76.64 \\
\hline $12-2 \mathrm{AM}$ & 1.553 & 0.321 & 1.232 & 79.34 \\
\hline $2.4 \mathrm{AM}$ & 1.910 & 0.355 & 1.555 & 81.40 \\
\hline 4-6 AM & 1.723 & 0.311 & 1.412 & 81.95 \\
\hline 6-8 AM & 2.024 & 0.367 & 1.657 & 81.87 \\
\hline
\end{tabular}

${ }^{1}$ Lights on from 8 a.m. to 10 p.m.

${ }^{2}$ Weights recorded in grams, then converted to pounds by multiplying by 0.0022 .

\section{PARTIAL DRYING OF MANURE}

The data presented in Table 3 were taken during June and July 1973. The manure was removed once daily at 8 a.m. Each test was for five consecutive days, thus the data are five-day averages. The average temperature and humidity are based on readings taken at 6 a.m., noon, 6 p.m., and midnight.

The weight and moisture content of the manure removed from the chamber daily provided the basis for determining the weight of the fresh manure, the dry material, and the weight and per cent of the water evaporated assuming an original moisture content of $\mathbf{8 0}$ per cent. The actual moisture content measured daily ranged between 82 and 85 per cent which was higher than the moisture content for the total volume collected for 24 hours (Figure 6 and Tables 1 and 2). To be conservative about the amount of in-house evaporation, the fresh moisture content was assumed to be 80 per cent, which may be high for some strains of laying hens.

The quantity of air (cfm/bird) blown over the manure has considerable influence on the amount of moisture removed (Table 3). Where no air was 


\section{TABLE 2}

\section{Accumulation of Fresh Manure, Moisture, and Dry Material}

From 100 Laying Hens at 2-Hour Intervals for 24 Hours.

\begin{tabular}{ccccc}
\hline \hline Time & $\begin{array}{c}\text { Fresh } \\
\text { Weight } \\
\text { (lbs.) }\end{array}$ & $\begin{array}{c}\text { Dry } \\
\text { Weight } \\
\text { (lbs.) }\end{array}$ & $\begin{array}{c}\text { Moisture } \\
\text { Weight } \\
\text { (lbs.) }\end{array}$ & $\begin{array}{c}\text { Moisture } \\
\text { Content } \\
\text { (per cent) }\end{array}$ \\
\hline 8-10 AM & 5.284 & 0.781 & 4.503 & 85.22 \\
10-12 AM & 8.478 & 1.396 & 7.102 & 83.77 \\
12-2 PM & 11.829 & 1.943 & 9.886 & 83.57 \\
2-4 PM & 14.938 & 2.506 & 12.432 & 83.22 \\
4-6 PM & 17.893 & 3.039 & 14.854 & 83.01 \\
6-8 PM & 20.749 & 3.622 & 17.127 & 82.54 \\
8-10 PM & 23.244 & 4.141 & 19.103 & 82.18 \\
10-12 PM & 24.929 & 4.535 & 20.394 & 81.80 \\
12-2 AM & 26.483 & 4.856 & 21.627 & 81.66 \\
2-4 AM & 28.393 & 5.211 & 23.182 & 81.64 \\
4-6 AM & 30.116 & 5.522 & 24.594 & 81.66 \\
6-8 AM & 32.320 & 5.889 & 26.431 & 81.77 \\
\hline
\end{tabular}

${ }^{1}$ Lights on from 8 a.m. to 10 p.m.

${ }^{2}$ Weights recorded in grams, then converted to pounds by multiplying by 0.0022 .

provided through the auxiliary air duct system, the loss of moisture was 11 per cent in 24 hours. As the rate of re-circulated air flow increased from 2.17 to $4.46 \mathrm{cfm} /$ bird, the quantity of moisture removed increased ${ }^{*}$, from 42 to 67 per cent.

At the $4.09 \mathrm{cfm} /$ bird rate (line six of Table 3) moisture evaporated in the house was slightly less (65 per cent) than for the 3.71 and $4.46 \mathrm{cfm} / \mathrm{bird}$ rates due to a substantially higher relative humidity (78 per cent as compared to 70 and 72 per cent).

The total and per bird air flow rates are given in Table 4 . The left side of the table shows that $575 \mathrm{cfm}$ was exhausted from the chamber when no air was re-circulated. As the rate of re-circulated air increased from zero to $642 \mathrm{cfm}$, the air exhausted decreased from 575 to $340 \mathrm{cfm}$. On a per bird basis, shown on the right side of the table, four cfm was exhausted from the chamber when no air was re-circulated. As the rate of re-circulated air increased from 2.17 to $4.46 \mathrm{cfm}$ per bird the air exhausted decreased to $2.36 \mathrm{cfm}$. This decrease in exhaust air may not be desirable during warm weather but may be advantageous during cold weather to conserve heat.

* The decline in total manure volume during the time $3.12 \mathrm{cfm} / \mathrm{bird}$ was used was due to bird illness caused by a lack of Vitamin $E$ in the feed. Egg production dropped severely and several birds died. 
TABLE 3

Effects of In-House Air Blown at Different Rates Over Manure to Evaporate Moisture 1

\begin{tabular}{ccccccccc}
\hline \hline $\begin{array}{c}\text { Auxiliary } \\
\begin{array}{c}\text { Air } \\
\text { (cfm/bird) }\end{array}\end{array}$ & $\begin{array}{c}\text { Chamber } \\
\text { Temperature } \\
\left({ }^{\circ} \text { F) }\right.\end{array}$ & $\begin{array}{c}\text { Chamber } \\
\text { Rel. Hum. } \\
\text { (per cent) }\end{array}$ & $\begin{array}{c}\text { Fresh } \\
\text { Manure } \\
\text { (lbs.) }\end{array}$ & $\begin{array}{c}\text { Meight } \\
\text { (lbs.) }\end{array}$ & $\begin{array}{c}\text { Moisture } \\
\text { (per cent) }\end{array}$ & $\begin{array}{c}\text { Material } \\
\text { (lbs.) }\end{array}$ & (lbs.) & (per cent) \\
\hline None & 71 & 64 & 33.30 & 30.28 & 78 & 6.66 & 3.02 & 11 \\
2.17 & 78 & 70 & 33.75 & 22.50 & 70 & 6.75 & 11.25 & 42 \\
2.76 & 75 & 65 & 36.90 & 20.50 & 64 & 7.38 & 16.40 & 56 \\
3.12 & 81 & 75 & 31.60 & 15.80 & 60 & 6.32 & 15.80 & 63 \\
3.71 & 79 & 70 & 32.14 & 14.95 & 57 & 6.43 & 17.19 & 67 \\
4.09 & 79 & 78 & 25.30 & 12.05 & 58 & 5.06 & 13.25 & 65 \\
4.46 & 84 & 72 & 23.95 & 11.15 & 57 & 4.79 & 12.80 & 67 \\
\hline
\end{tabular}

${ }^{1}$ All data are averages for five consecutive days.

${ }^{2}$ Based on house capacity of 144 birds.

${ }^{3}$ Assumed to contain 80 per cent moisture (w.b.)

${ }^{4}$ All weights and per cents based on manure removed once daily. 
TABLE 4

Total and Per Bird Air Flow Rates

\begin{tabular}{|c|c|c|c|c|c|c|}
\hline \multirow[b]{2}{*}{$\begin{array}{l}\text { Orifice } \\
\text { Diameter } \\
\text { (inches) }\end{array}$} & \multicolumn{3}{|c|}{ Chamber Air Flow } & \multicolumn{3}{|c|}{ Air Flow Per Bird ${ }^{1}$} \\
\hline & $\begin{array}{l}\text { Total } \\
\text { (cfm) }\end{array}$ & $\begin{array}{l}\text { Recirculated } \\
\text { (cfm) }\end{array}$ & $\begin{array}{c}\text { Exhausted } \\
\text { (cfm) }\end{array}$ & $\begin{array}{l}\text { Total } \\
\text { (cfm) }\end{array}$ & $\begin{array}{l}\text { Recirculated } \\
\text { (cfm) }\end{array}$ & $\begin{array}{l}\text { Exhausted } \\
\text { (cfm) }\end{array}$ \\
\hline- & 575 & 0 & 575 & 4.00 & 0 & 4.00 \\
\hline 3 & 728 & 313 & 415 & 5.05 & 2.17 & 2.88 \\
\hline 4 & 763 & 397 & 366 & 5.30 & 2.76 & 2.54 \\
\hline 5 & 810 & 449 & 361 & 5.63 & 3.12 & 2.51 \\
\hline 6 & 889 & 535 & 354 & 6.17 & 3.71 & 2.46 \\
\hline 8 & 936 & 589 & 347 & 6.50 & 4.09 & 2.41 \\
\hline 10 & 982 & 642 & 340 & 6.82 & 4.46 & 2.36 \\
\hline
\end{tabular}

${ }^{1}$ Based on cage capacity of 144 laying hens. 